\title{
Study the Effect of Some Physical and Chemical Agents on Growth of Enterobacter Sazkazakii Isolated from Local Foods
}

\author{
May H. Shafeek \\ Department of Biology, Collage of Science, Baghdad University.
}

\begin{abstract}
This research was performed to study the effect of some physical \& chemical material which found domestically in order to control the growth of E. sakazakii. The effect of different concentrations of $\mathrm{NaCl}$ exhibit that $3.5 \%$ of the salt killed the bacteria after 30 min of incubation, while the low concentration showed a less inhibition in numbers of cells.

In using different concentrations of chlorine showed that $6 \%$ concentration was effective in killing the bacteria in $10 \mathrm{~min}$, while $9 \%$ conc. destroyed the bacteria in $5 \mathrm{~min}$. when using different conc. of citric acid reaching pH: $5 \& 3$ bacterial growth inhibited to low levels in comparing the control. And when we use $\mathrm{NaOH}$ to gain a pH: $9 \& 11$ bacterial growth were inhibited to $40 \& 25$ colony forming unit/ml after $30 \mathrm{~min}$. of incubation.
\end{abstract}

\section{Introduction}

Enterobacter sakazakii causes different diseases such as : meningitis, enterocolitis and septicemia especially for neonates and infants (less than 6 month) which were fed by prepared infant formula [1], the rate of mortality was very high which estimated between 40-80\% [2], while in recovered persons a severe neurological sequelae has been occurred [2]. This bacteria was also found in blood and urine specimens of adult patients suffering from: osteomyelitis, ophthalmic infection, endocarditis and urinary tract infection [3]. This bacteria was also isolated from feeding bottles and instrument which used for infant preparing formula in hospitals and nurseries [1] the bacteria was also isolated from fruits, vegetables, meat and dairy product [4].

For these reasons this study was proposed in order to study the effect of domestic materials to control bacterial growth in houses, nurseries, and hospitals.

\section{Material and Methods}

This bacteria was isolated from different food samples (500 $\mathrm{g}$ weight for each) such as: lettuce, cabbages, green vegetables, cucumber, tomato, local Arab cheese and minced meat all these food were taken from local markets.

The isolation method was done according to FDA [5]:

A-) presumptive test by using EE broth

(Enterobacteriaceae enrichment broth).
B-) Identification of the isolates was accomplished on VRBG media (Violate red bile glucose agar).

C-) Step B was repeated to confirm the test.

D-) Cultivation was achieved on tryptic soya agar by direct streaking.

E-) For positive identification of E. sakazakii Oxidase test must be included. Then several biochemical tests were done such as:

\section{1-) Effect of Sodium chloride ( $\mathrm{NaCl}$ )}

The effect of different concentrations of $\mathrm{NaCl}$ was studied by taking 6 tubes containing Potassium Phosphate buffer and $\mathrm{NaCl}$ was added in a final concentration: $3.5 \%, 2.5 \%$, $1.5 \%, 0.9 \%$, and $0.5 \%$. One tube was left without $\mathrm{NaCl}$ as a control.

The tubes was sterilized and $0.1 \mathrm{ml}$ of bacterial culture (18 hr. age) was added. All tubes were incubated at $37^{\circ} \mathrm{C}$ for 10,20 , and $30 \mathrm{~min}$.

There after bacteria was counted by spreading on TSA (Tryptic soya Agar) [6].

\section{2-) Effect of chlorine}

Four flasks were taken, each flask contain $20 \mathrm{ml}$ sterilized distilled water where the chlorine was added in a final concentration of: $3 \%, 6 \%, 9 \%$, while the $4^{\text {th }}$ one was left without addition as a control, then was added to each flask $0.1 \mathrm{ml}$ of bacterial suspension which was cultivated in brain heart infusion broth (18 hr. age). All flasks were incubated. at $25^{\circ} \mathrm{C}$ and for $1,5,10 \mathrm{~min}$. time interval through that total viable count was done by 
using sterile peptone water for the dilution and Trypic Soya Agar for the bacterial count [1].

*Note:

Chlorine used: Is fast (from Babylon company for making soaps and detergent limited - Baghdad)

Total concentration was $6.2 \%$.

\section{3-) Effect of pH :}

A-) Preparing alkaline media :

Three test tubes were taken and each one contained $9 \mathrm{ml}$ of potassium phosphate buffer then $\mathrm{pH}$ was adjusted in the test tubes by adding sodium hydroxide [2 M] to be:

$$
\begin{array}{ll} 
& 1^{\text {st }} \text { tube } \mathrm{pH} 9, \\
& 2^{\text {nd }} \text { tube } \mathrm{pH} 11, \\
\text { control } & 3^{\text {rd }} \text { tube } \mathrm{pH} 7
\end{array}
$$

The tubes were sterilized and left until use.

B-) Preparing acid media :

Two tubes were taken: each one contained $9 \mathrm{ml}$ of potassium phosphate buffer. The $\mathrm{pH}$ was adjusted by citric acid to be :

$1^{\text {st }}$ tube $\mathrm{pH} 5$

$2^{\text {nd }}$ tube $\mathrm{pH} 3$

The tubes sterilized and left until use.

To the A and B tubes $0.1 \mathrm{ml}$ of bacterial suspension (18 hr. old) was added. All tubes were incubated at $21^{\circ} \mathrm{C}$, and bacterial viable count was done at: $5,10,20,30 \mathrm{~min}$. by spreading on TSA media [7].

\section{Result and Discussion}

\section{1-) Isolation and diagnosis of bacteria}

A-) Colonies of E. sakazakii appeared purple surrounded by a purple halo of precipitated bile acids on VRBG agar [5].

B-) Colonies of the same bacteria appeared yellow pigmented colonies on TSA media [5].

C-) This bacteria gave a positive oxidase test and it is an important test because it distinguish between this bacteria and Enterobacter cloacae which was oxidase negative, and this proved by Nazarowee et al (8) and they proved also that $\underline{E}$. sakazakii and $\underline{E}$ cloacae are different from each other genetically .
D-) Eight isolate were chosen from different kinds of food to study the effect of different chemical agents.

\section{2-) Effect of Sodium chloride ( $\mathrm{NaCl})$ :}

It was noticed from Fig.(1) that the bacteria was in its best growth at $0.9 \%$ of $\mathrm{NaCl}$. Results revealed that numbers of bacteria were much more than control numbers, but when salt concentration was increased the numbers began to decrease till it disappeared at the concentration $3.5 \%$ of the salt and after $30 \mathrm{~min}$ of incubation, while Lambert et al (6) mentioned that the bacteria resist salt concentration till $12 \%$ then it began to die, this different may be because the bacteria in laboratory was cultivated in phosphate buffer media while Lambert et al (6) cultivated it on all organic media, also, Lambert et al (6) noticed that the initial numbers and exposure time to salt affected cell resistant.

The effect of salt on bacterial cell was due to increase in salt concentration would led to osmotic shock to the cells [6]. Also Lambert et al (9) mentioned that the reason of growth inhibited may be because of chloride ion. 


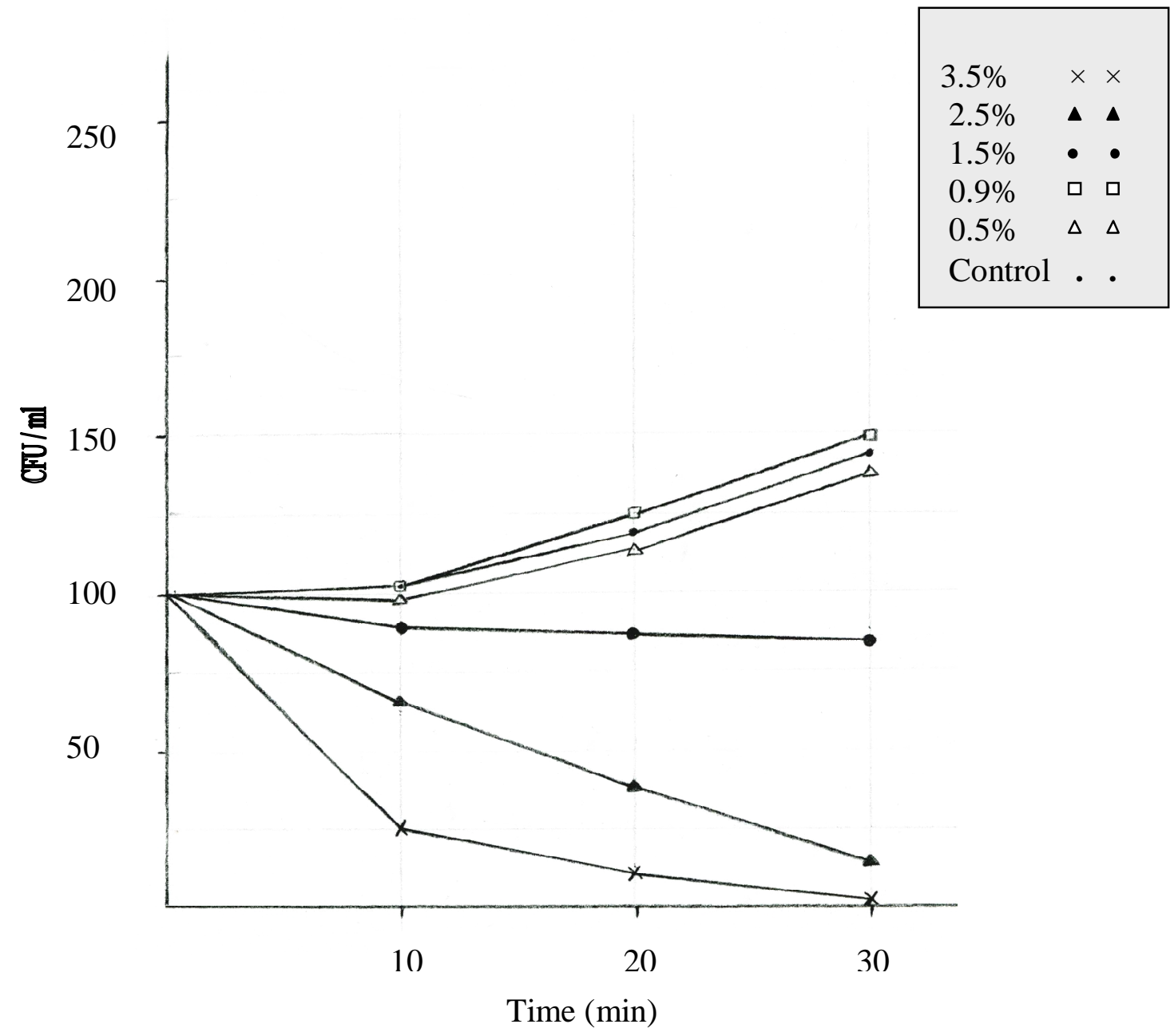

Fig. (1) Effect of different concentrations of NaCl on E. sakazakii growth.

\section{3-) Effect of chloride ion :}

It was noticed from Fig.(2) that even in low concentrations of chlorine there was a clear inhibition of bacterial growth even in short time incubation, and when the concentration was increased to $6 \%$ [which is used domestically] the growth disappeared after $10 \mathrm{~min}$. of exposure to chlorine, and when increase to $9 \%$ bacterial growth was disappered after $5 \mathrm{~min}$., that is similar to (10) who said that washing fruits, vegetables, Apples, Tomato and lettuce with chlorine solution $[10 \mathrm{Mm} / \mathrm{ml}]$ for $1-5 \mathrm{~min}$. was enough to kill the bacteria on apple and tomato and decrease the numbers of bacteria on lettuce. The effect of chlorine on bacterial count attributed to the release of tissue juices which increased the concentration of soluble organic materials available for reaction with chlorine [11], also [11] mentioned that resistant of bacteria to detergents depend basically on: detergent structure and its kind, time of exposure, quantity of detergent, and age of the bacteria. Also chlorine in water forms hypochlorous and hydrochloric acid :

$$
\mathrm{Cl}_{2}+\mathrm{H}_{2} \mathrm{O} \rightarrow \mathrm{HCl}+\mathrm{HClO} \rightarrow \mathrm{HCl}+\mathrm{O}
$$

The Oxygen released in this reaction is a strong oxidizing agent and through its action cellular constituents will be destroyed [A]. 


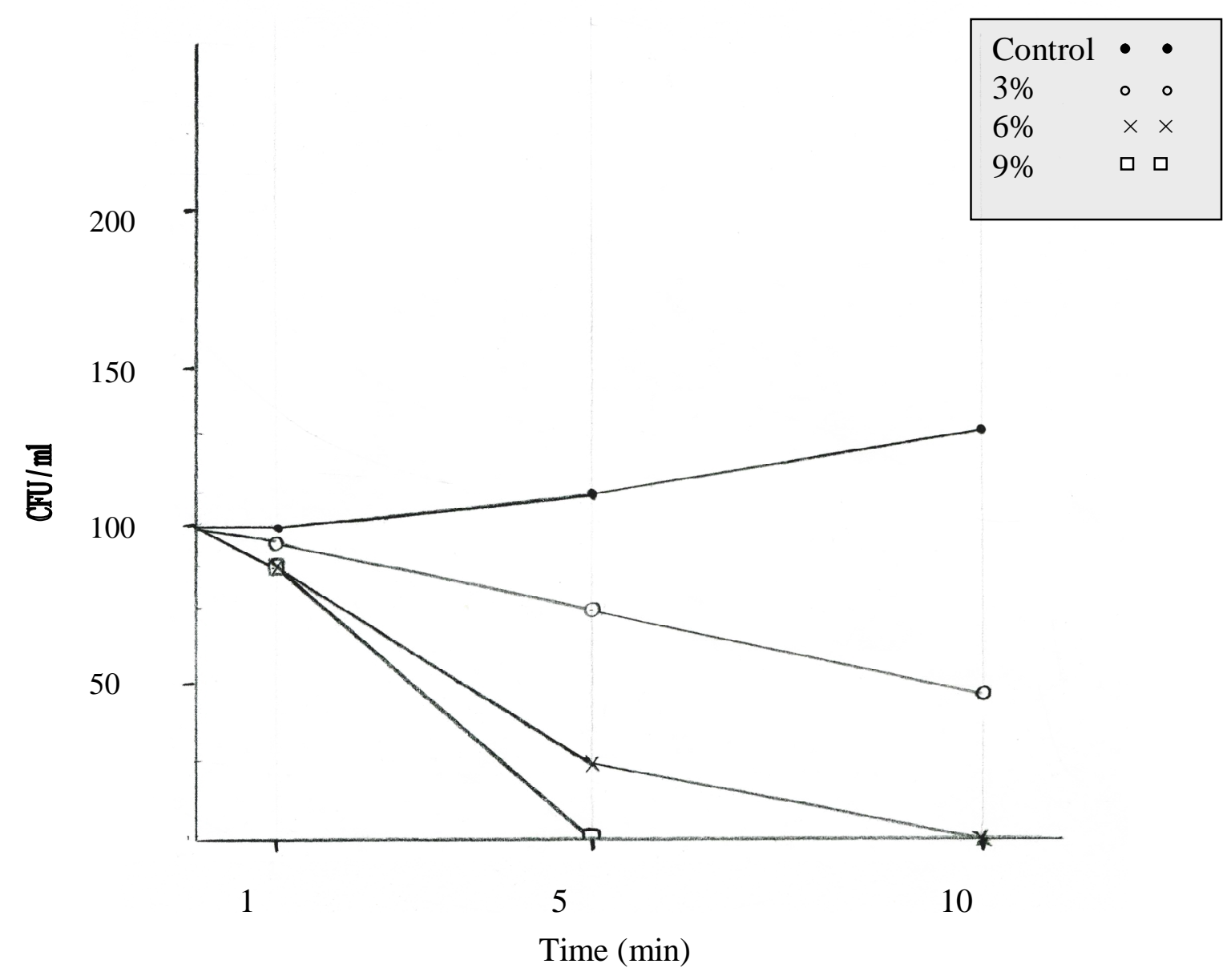

Fig.(2) Effect of different concentrations of chlorine on $\underline{\underline{E}}$ sakazakii growth.

\section{4-) Effect of pH :}

It was noticed from Fig. (3) that the highest growth was in $\mathrm{pH} 7$ but when it increased to 9 and 11, bacterial growth decrease until the end of incubation time which was $30 \mathrm{~min}$., and we noticed the same thing at $\mathrm{pH} 5$ and $\mathrm{pH} 3$ the bacterial count decrease to $10 \mathrm{CFU} / \mathrm{ml}$ at the end of incubation, this result agreed with Edelson et al (12) who mentioned that the bacteria resist acid effect for $5 \mathrm{hr}$. at $36^{\circ} \mathrm{C}$. Also Mendonca et al (13) revealed that the high or low concentration of acid had a quick damage to pathogenic gram negative bacteria, also they mentioned that there is a direct relationship between primal release of materials and death of cells, they noticed that cells at $\mathrm{pH} 12$ began to die and lysis while gram positive bacteria didn't reveal that. Also Mendonca et al (13) noticed that the causes of damage of pathogenic gram negative bacteria due to cytoplasmic membrane rupture. Also kim and
Beuchat [6] reported that the effect of $\mathrm{pH}$ on bacterial cell depends on:

Age of bacterial cell, ingredients of media, temperature and time of exposure to acid or alkaline. 


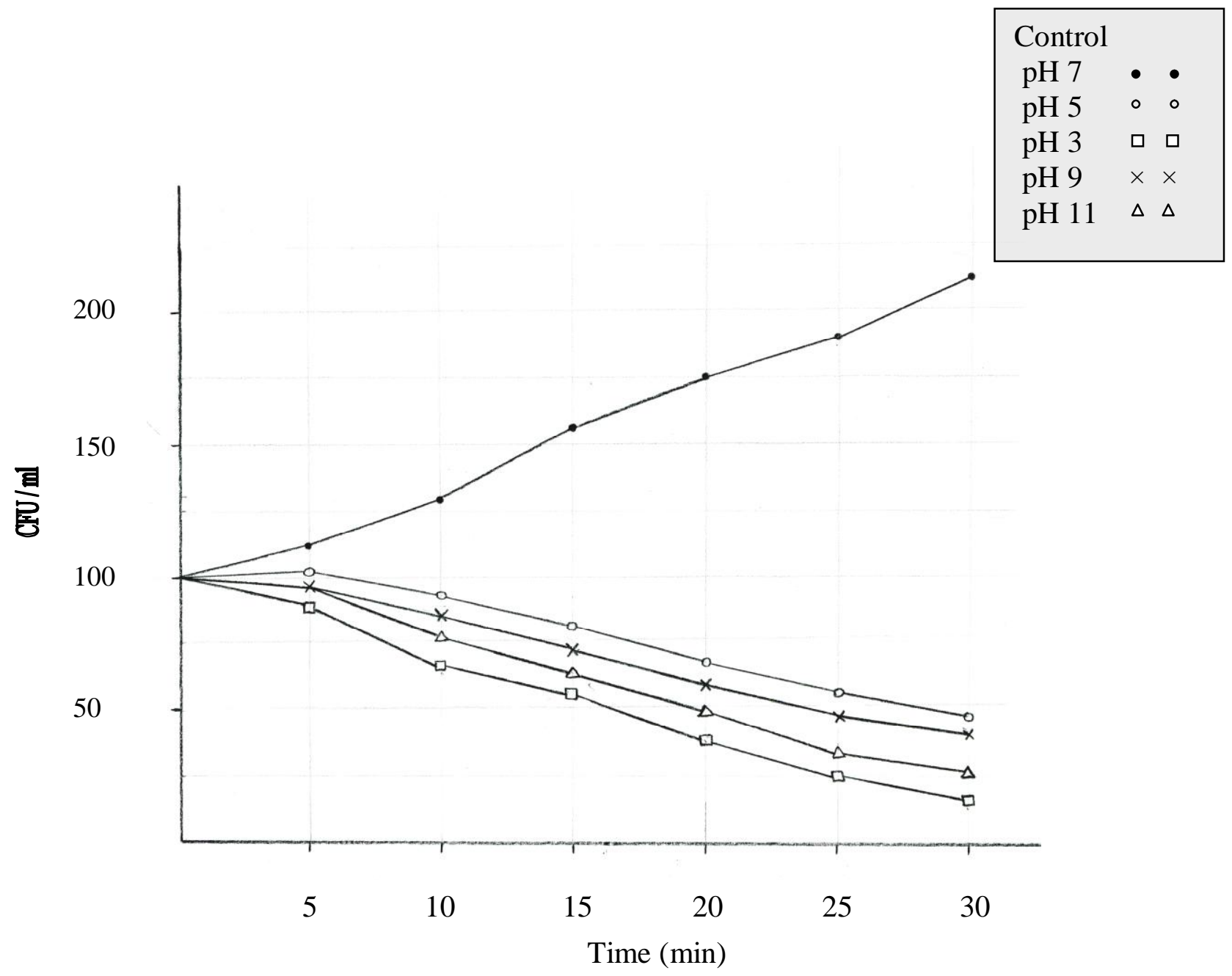

Fig.(3) Effect of pH on bacteria $\underline{\text { E. sakazakii }}$ growth.

\section{References}

[1] H. B. Kim; J. H Ryu, and L.R. Beuchat. "Effectiveness of Disinfectant in Killing E. sakazakii in suspension, Dried on the surface of stainless steel and in a Biofilm". Appl. Environ. Microbial. Vol. 73. No. 4, 2007. pp. 65-1256.

[2] M. nazar owe-white, and J. M. Farber. "Thermal resistance of E. sakazakii in recon stituted dried-infant formula". Lett. Appl. Microbial. Vol. 24,1, 1997, pp. 9-13.

[3] R. E. Hawking; CR, Lissner and JD Sanford. "Enterobacter sakazakii bacterium in an adult" J. P. Vol. 84, No. 6, 1991, pp. 793-795.

[4] H. B. Kim; and L. R. Beuchat. "Survival and growth of $\underline{\mathrm{E}}$. sakazakii on fresh-cut fruits \& vegetable and in pasteurized juice as affected by storage temperature". J. food prot. Vol. 68, No. 12, 2005, pp. 25412552.
[5] U.S. Food and Drug Administration [FDA] "Isolation enumeration of E. sakazakii from dehydrated powdered infant formula" 2002 pp. 1-6.

[6] R. J. W. Lambert; and E. Bedlas. "Comparing the antimicrobial effectiveness of $\mathrm{NaCl} \& \mathrm{KCl}$ with a view to salt replacement". International J. Food. Microbial. Vol. 124, 2008, pp. 98-102.

[7] J.B. Gurtler; and L.R. Beuchat. "Performance of media for recovering stressed cells of E. sakazakii as determined using spiral plating \& Ecometric techniques". Appl. Environ. Microbial. Vol. 71, No. 12, 2005, pp. 7661-7669.

[8] M. Nazarowee-white; and J. M.. Farber. "E. sakazakii : a review". J.Food. Microbial. Vol. 34, No. 2, 1997, pp. 103113.

[9] R.J.W. Lambert; and E. Bidlas. "An investigation of the Gamma hypothesis: A 
predictive modeling study of the effect of combined inhibitors [salt, $\mathrm{PH}$, and week acid] on the growth of Aeromaonas hydrophila". International J. of food Microbiology. Vol. 115, 2007, pp. 12-28.

[10] H. Kim; JH Ryu; and L.R. Beuchat. "Survival of E. sakazakii on fresh produce as effected by temperature, and effectiveness of sanitizers for its elimination". J. Food. Microbial. Vol. 111, No. 2, 2006, pp. 134-143.

[11] L.R. Beuchat; B.B. Adler; and M.M. Long. "Efficacy of Chlorine and \& peroxy acetic acid sanitizer in killing Listeria monocytogenes on icebering \& Romania lettuce using simulated commercial processing conditions". $J$. Food Prot. CAB Abstract. 5/1-2009.

[12] S. Edelson - Mammel ; M.K. Proteous; and R.L. Buchanan. "Acid resistance of 12 strains of E. sakazakii and the impact of Habituating the cells to a acid environment". J. Food science. Vol. 71, No. 6, 2006, pp. 201-207.

[13] A. F. Mendonca ; T. L. Amorosa ; and S. J. Knabel. "Destruction of $\mathrm{G}$-ve Food borne pathogens by high $\mathrm{PH}$ involves distribution of the cytoplasmic membrane". Appl. Environ. Microbial. Vol. 60, No. 11, 1994, pp. 4009-4014.

[14] كتاب علم الأحباء المجهرية، تأليف لجنة من أساتذة

علوم الأحياء المجهرية. "السيطرة على ندو الاحباء المجهية" 1991 كلية العلوم / جامعة بغداد.

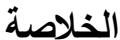

اجري هذا البحث لغرض دراسة تأثنير عدد من العوامل

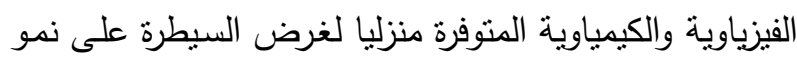

بكتريا E. sakazakii المسببة للعديد من الأمراض الخطرة إذ

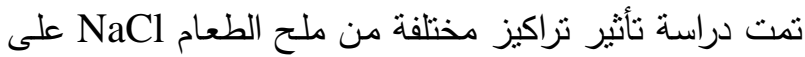

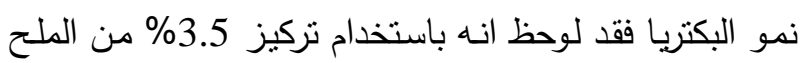

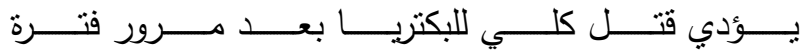
30 دقيقة على المعاملة بالملح في حين كانت التراكيز الأقل من ذلك أقل تثبيط لنمو البكتريا. وفي حالة استخدام تراكيز

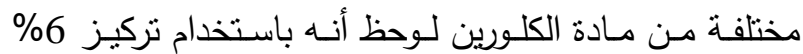

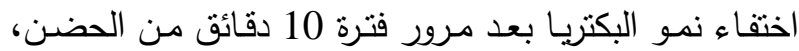
وباستخدام تركيز 9\% لوحظ اختفاء النمو نهائيا بعد مرور فترة 5 دقائق فقط من الحضن.

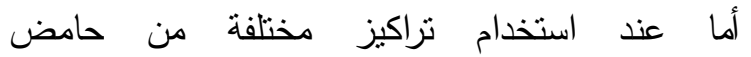

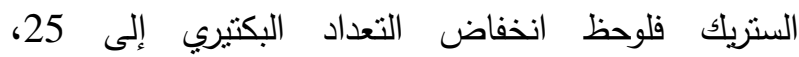
15 مستعمرة/ مل وخفض الأس الهيدروجيني إلى 5 و 3 وعلى التوالي خلال مدة الحضانة 30 دقيقة؛، وباستخدام هيدروكسيد الصوديوم لوحظ أيضـا انخفاض التعداد البكتيري إلى 40لى 40، 25

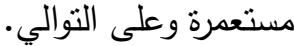

